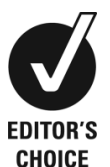

CHOICE

\title{
Capillary haemangioma on the palate: a diagnostic conundrum
}

\author{
Pooja Singh, ${ }_{1}^{1}$ Anuj Singh Parihar, ${ }^{2}$ Sana Noor Siddique, ${ }^{3}$ Pooja Khare ${ }^{4}$
}

${ }^{1}$ Department of Oral Medicine and Radiology, Maharana Pratap College of Dental Sciences and Research Centre, Gwalior, Madhya Pradesh, India

${ }^{2}$ Deaprtment of Periodontics, People's College of Dental Sciences and Research Centre, Bhopal, Madhya Pradesh, India ${ }^{3}$ Department of Oral Medicine and Radiology, People's College of Dental Sciences and Research Centre, Bhopal, Madhya Pradesh, India ${ }^{4}$ Department of Oral Medicine and Radiology, People's Dental Academy, Bhopal, Madhya Pradesh, India

\section{Correspondence to}

Dr A S Parihar,

dr.anujparihar@gmail.com

Accepted 27 January 2016



To cite: Singh $P$ Parihar AS, Siddique SN, et al. BMJ Case Rep Published online: [please include Day Month Year] doi:10.1136/bcr-2015210948

\section{SUMMARY}

Haemangiomas are benign tumours of blood vessel origin and are classified as capillary, cavernous or central. They appear as flat or raised reddish-blue lesions and are generally solitary, affecting women in younger age groups. The tumour may be slowly progressive, involving extensive portions of the superficial and deep blood vessels, and affect function, depending on location. They are common in the head and neck region but rarely in the oral cavity. Oral lesions generally appear on the lips, buccal mucosa and tongue, but rarely on the palate. As the lesion can be confused with pyogenic granuloma, histopathological examination is important for a final diagnosis. The case presented here signifies a rare location of a capillary haemangioma on the palate in a middle aged man. The lesion was diagnosed by histopathology after surgical excision.

\section{BACKGROUND}

The term haemangioma is a generic one used to describe congenital hamartomas and vascular malformations. In general, haemangiomas are developmental and are often recognised at an early stage. They are considered to be the most common tumour of childhood, occurring in about $5-10 \%$ of children $<1$ year of age, exhibiting a rapid growth phase with endothelial cell proliferation followed by gradual involution. ${ }^{2}$ There is however an additional neoplastic form that appears in middle life or in older people. ${ }^{1}$ In the oral cavity they may occur in any area, at any age, without any racial or gender predilection. However, more than $50 \%$ are found in patients $>40$ years of age. The lips, buccal mucosa and tongue are the most common sites of occurrence, while the hard and soft palates and uvula are rarely affected. ${ }^{3}$ There occurrence on the palatal mucosa is extremely rare.

The present case is of importance in view of the involvement of the hard palate, an extremely rare site (ie, hard palate involvement in an older age group). ${ }^{4}$

\section{CASE PRESENTATION}

A 31-year-old man presented with a growth on the left anterolateral part of the hard palate of 3 years' duration with a complaint of discomfort during mastication and speech. The growth was the size of a peanut when he first noticed it 3 years previously and had grown to the present size. The growth was asymptomatic; there was no history of pain, pus discharge or bleeding, or any other secondary symptoms. His medical dental and family history was non-contributory.

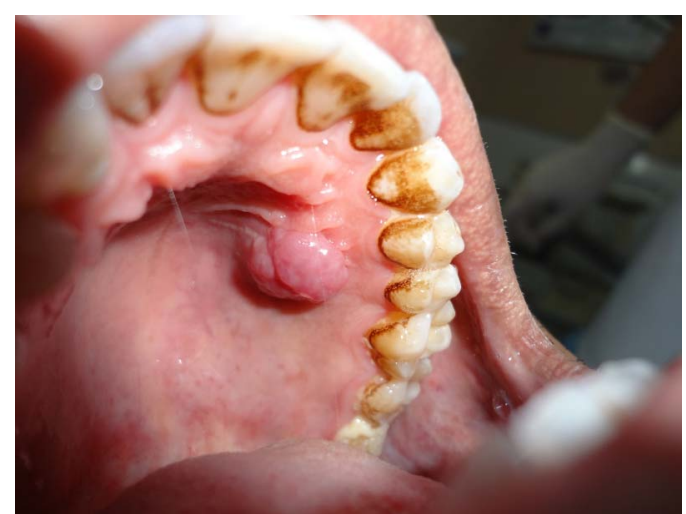

Figure 1 Intraoral view.

Intraoral soft tissue examination revealed a solitary broad based spherical pink growth with a well defined border and pebbly surface. It was present on the left anterolateral part of the hard palate just $2 \mathrm{~cm}$ lateral to the midline on the left side in an area between the maxillary first and second premolars, measuring about $1.5 \mathrm{~cm}$ in diameter. On palpation it was non-tender, soft to firm in consistency, compressible but not reducible and non-pulsatile. The patient's oral hygiene status was fair and no other relevant intraoral findings were evident (figure 1).

Based on clinical signs and symptoms, a provisional diagnosis of pyogenic granuloma was established. Due to the relatively small size of the lesion, an excisional biopsy, along with histopathologic evaluation, was recommended as the diagnostic approach.

\section{INVESTIGATIONS}

Intraoral periapical radiograph in relation to 24,25 and 26 did not reveal any pathological changes.

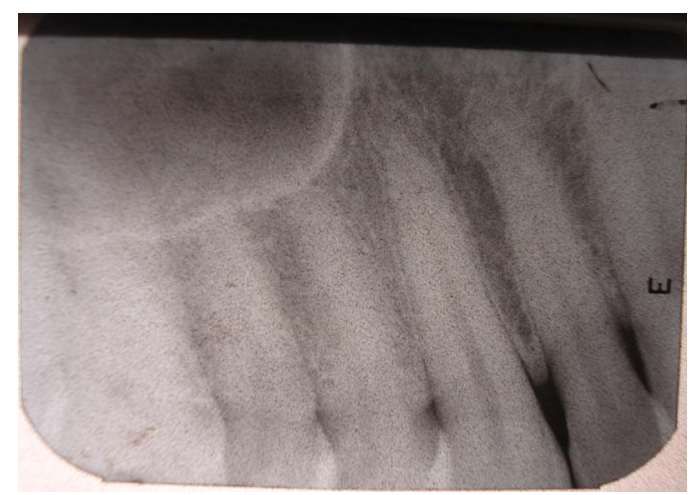

Figure 2 Periapical radiograph showing 24, 25 and 26. 


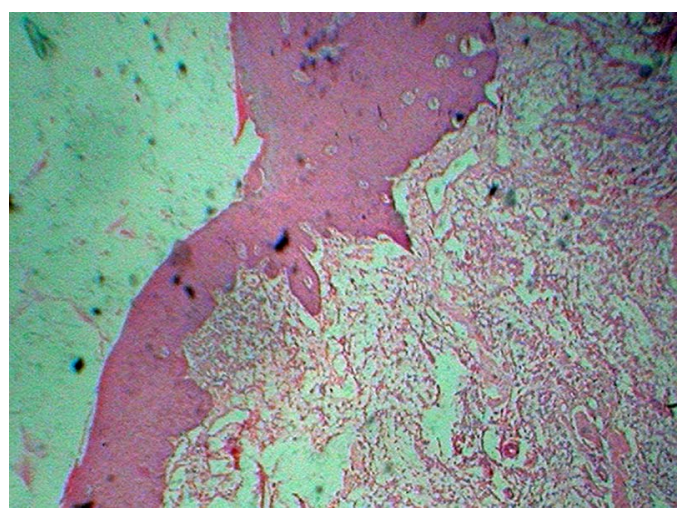

Figure 3 Histophotograph showing parakeratinised stratified squamous epithelium.

The complete haemogram was within normal limits (figure 2).

The histopathological examination of the excised mass showed parakeratinised stratified squamous epithelium of varying thickness (figure 3). The fibrous connective tissue showed numerous endothelial lined blood vessels of varied sizes and few blood vessels, which were yet to be lumenised. Numerous mixed inflammatory components were present (figure 4). Histopathological features were suggestive of capillary haemangioma with an inflammatory component. The inflammatory component in histopathological examination can be due to trauma. Hence on correlation of the clinical and histological findings, a final diagnosis of capillary haemangioma was established.

\section{DIFFERENTIAL DIAGNOSIS}

The differential diagnosis of peripheral ossifying fibroma was made due to the similar clinical presentation of the lesion. However, the peripheral ossifying fibroma shows resorption of bone at the site of the lesion and radiographs are advised to rule out bony destruction, but no such finding was detected in the intraoral radiograph taken. Another similar appearing lesion taken into consideration was irritational fibroma, as the lesion appeared to be red to purple with a pebbly surface and on palpation it was compressible.

\section{TREATMENT}

As the lesion was small in size, an excisional biopsy was done under local anaesthesia. There was excessive bleeding at the time of biopsy, which was controlled after application of pressure packs and local styptics.



Figure 4 Histophotograph showing a mixed inflammatory component.

\section{OUTCOME AND FOLLOW-UP}

Wound healing was uneventful and no recurrence was noted after 5 months of follow-up.

\section{DISCUSSION}

Haemangiomas, whether they represent a true neoplasm, malformation or hamartomas, have been the subject of continuous debate, and use of the terms haemangioma and malformation can be confusing. ${ }^{3}$

Most pathologists separate haemangioma, composed primarily of blood vessels of similar size and type, from malformations, composed primarily of arteries and veins of varying sizes. ${ }^{3}$ In 1982, Mulliken and Glowaki developed a classification of vascular tumours based on endothelial characteristics. ${ }^{5}$

Haemangiomas of the oral cavity may exist as small or large superficial growths with varying degrees of penetration into soft tissues or as monstrous growths extending to the oesophagus. They may also be multicentric with a cobblestone appearance. ${ }^{6}$ Most of the small superficial lesions, especially pedunculated ones, tend to be capillary haemangiomas, whereas the large superficial or deep lesions tend to be of the cavernous or mixed variety. ${ }^{7}$

Capillary haemangiomas can be sessile or pedunculated, soft, smooth or irregular, and bulbous in outline, and are painless unless traumatised. They vary in colour from deep red to purple and blanch on application of pressure. Those on the palatal mucosa are solely of the capillary type. ${ }^{1}$ In the present case, the lesion was broad based, red to purple with a pebbly surface. Periodontally they may appear to arise from the mediolateral gingival papillae and spread laterally to involve adjacent teeth. ${ }^{1}$ However, in the present case, the lesion was not attached to the gingiva and was $1 \mathrm{~cm}$ medial to it.

This varied appearance, infrequent association with palatal gingival and tendency to mimic other lesions leads to confusion with other clinical entities, such as pyogenic granuloma, chronic inflammatory gingival hyperplasia, epulis granulomatosa, telegenctesia, angiosarcoma or squamous cell carcinoma. ${ }^{18}$ In the present case, with the clinical appearance, a working diagnosis of pyogenic granuloma was assumed; however, histopathological examination confirmed a diagnosis of capillary haemangioma.

The usual capillary haemangioma is composed of many small capillaries lined by a single layer of endothelial cells, supported by a connective tissue stroma of varying density. It bears considerable resemblance to the young granulation tissue and is mostly identical to some cases of pyogenic granuloma. Some cases show remarkable endothelial cell proliferation. ${ }^{49}$

Management is based on several factors, such as age of the patient, size, extent and clinical characteristics of the lesion. The smaller lesions can be carefully and successfully excised, ${ }^{1}$ as in the present case. Most small capillary haemangiomas reported

\section{Learning points}

- The capillary haemangioma is a rare benign oral tumour but should be included in the differential diagnosis of oral benign growths.

- This entity can be confused with pyogenic granuloma and needs careful evaluation for a final diagnosis.

- Although small in size, this lesion has a tendency to bleed profusely during management.

- Adequate measures to control bleeding during surgery are encouraged. 
in the literature have been treated with excision or curettage. ${ }^{10}$ Local complications, such as bleeding or postoperative ulcerations, tend to occur. During excision in the present case, bleeding was controlled with application of pressure and/or styptics, while wound healing was uneventful in our case.

Twitter Follow Anuj Parihar at @anujhimself

Competing interests None declared.

Patient consent Obtained.

Provenance and peer review Not commissioned; externally peer reviewed.

\section{REFERENCES}

1 Acikgoz A, Sakallioglu U, Ozdamar S, et al. Rare benign tumours of oral cavitycapillary hemangioma of palatal mucosa: a case report. Int J Paediatr Dent 2000;10:161-5.

2 Neville BW, Damm DD, Allen CM, et al. Oral and maxillofacial pathology. 3rd edn. St Louis: Saunders, 2008.
3 Barnes $L$ Tumours and tumour-like lesions of the soft tissues. In: Barnes $L$, ed. Surgical pathology of the head and neck. New York, NY: Marcel Dekker, 1985:725-880.

4 Bayrak S, Dalci K, Hmza T. Capillary haemangioma of the palatal mucosa: report of an unusual case. Su Dishek Fak Derg 2010;19:87-9.

5 Mulliken JB, Glowaki J. Hemangioma and vascular malformation in infants and children: classification based on endothelial characterstics. Plast Reconstruct Surg 1982:69:412-20.

6 Cocke EW Jr. Cavernous hemangioma of the oral and hypopharynges. Am J Surg 1961;102:798-802.

7 Shklar G, Meyer I. Vascular tumors of the mouth and jaw. Oral Surg Oral Med Oral Pathol 1965; 19:335-58.

8 Gill JS, Gill S, Bhardwaj A, et al. Oral haemangioma. Case Rep Med 2012;2012:347939.

9 Rajendran R, Shivapathasundram B. Benign and malignant tumors of the oral cavity, Shafer's textbook of oral pathology. Reed Elsevier India Pvt Ltd, 2006.

10 Rachappa M, Trivedi MN. Capillary haemangioma or pyogenic granuloma: a diagnostic dilemma. Contem Clin Dent 2010;1:119-22.

Copyright 2016 BMJ Publishing Group. All rights reserved. For permission to reuse any of this content visit http://group.bmj.com/group/rights-licensing/permissions.

BMJ Case Report Fellows may re-use this article for personal use and teaching without any further permission.

Become a Fellow of BMJ Case Reports today and you can:

- Submit as many cases as you like

- Enjoy fast sympathetic peer review and rapid publication of accepted articles

- Access all the published articles

- Re-use any of the published material for personal use and teaching without further permission

For information on Institutional Fellowships contact consortiasales@bmjgroup.com

Visit casereports.bmj.com for more articles like this and to become a Fellow 